\title{
Analysis of the Relevance of 4-Year Diploma-in-Mechanical Engineering Course Curricula with Occupational Tasks of Shipbuilding Industries in Bangladesh
}

\author{
Mohammad Mahbubur Rahman ${ }^{1}$, Dr. Md. Abu Raihan ${ }^{2}$, \\ Dr. Md. Abdul Awal Khan ${ }^{3}$ \\ ${ }^{1}$ (M.Sc.T.E. student, TVE Department, IUT) \\ ${ }_{2}^{2}$ (Assistant Professor, TVE Department, IUT,) \\ ${ }^{3}$ (Visiting Professor, TVE Department \& Professor, University of Dhaka, Department of IER)
}

\begin{abstract}
This study was aimed to study the relevance/suitability of course curricula of Diploma-in-Mechanical engineering with the occupational tasks of ship building industries in Bangladesh. The total number of population was all the engineers and administrators who are working in Shipbuilding Industries in Bangladesh. The sample was selected by using the non-probability convenience sampling technique. Here the sample comprised subjects who were simply available in a convenient way and they were willing to cooperate for providing required information. The total sample of this study was 60 from selected famous Shipbuilding Industries those have a total set of instruments, manpower, environment, good administration and others required facilities. The results show that the occupational tasks of shipbuilding industries are very similar and relevant with 4-year Diploma-in-Mechanical Engineering course curricula and the syllabus is also well developed. The researcher recommended to develop the course of diploma in mechanical engineering to integrate with the shipbuilding industries in Bangladesh.
\end{abstract}

Keywords: - Analysis, Course Curricula, Relevance, Occupation, Occupation Task, Shipbuilding Industries.

\section{INTRODUCTION}

The shipbuilding industry in Bangladesh is now becoming a promising sector. Bangladesh is a maritime nation. It has long tradition of supplying reputed seafarers since British India Period. There are more than 200 rivers all around the country, with a total length of about $22,155 \mathrm{~km}$, which occupy about $11 \%$ of total area of the country (Iqbal-2010). At present more than 5,000 inland/coastal ships have been playing all over the country, which carry more than $90 \%$ of total oil product, $70 \%$ of cargo and $35 \%$ of passengers (Zakaria, 2010). Huge manpower is working in these sectors. More than 1,00,000 skilled workers and 150,000 semi-skilled workers are employed in this labor-intensive industry (Hossain, 2010). Around 200 shipyards and shipbuilding workshops, 10,000 inland vessels and 1,000 costal vessels are playing in Bangladesh Marine Sector (Iqbal2010). At present local shipbuilding companies can manufacturers around $40 \%$ of the components for vessels built for local demand. Two shipyards have already made it on the international scene and have at present around 50 vessels in their order books from Danish, German, Dutch and finish buyers. Recently few local shipyards have attained the capability to manufacture the ships of 10000 DWT as per international standards and they can be upgrade up to 50000 DWT in future (Marine TECH Bangladesh, 2013). The productivity for different shipbuilding nation around the world has been compared and shown in figure-1.

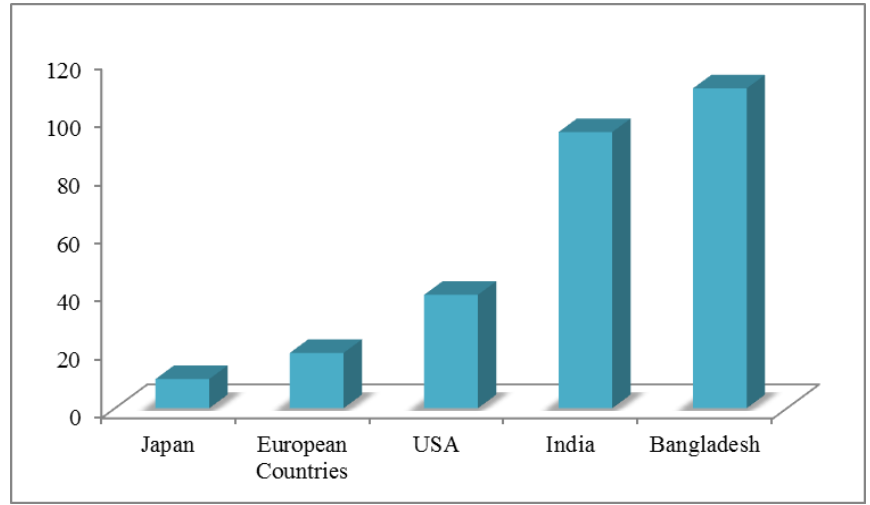

Figure: 1 Productivity of different countries 
The history of indigenous shipbuilding in Bangladesh was glorious. Bangladesh has a strong background in shipbuilding since ancient times. Regarding the development of shipbuilding industries in Bangladesh provided a description in a message in "International Seminar and Exhibition on Prospects of Shipbuilding Industry in the OIC Countries" venue was the Islamic University of Technology (IUT) which integrated that "Since 2005 Bangladesh is exporting ships to clients from Denmark, Mozambique, Germany, the Netherlands and Finland. Germanischer Lloyd has declared in 2008 Bangladesh as a shipbuilding nation of international standard." Regarding the development of shipbuilding in Bangladesh said, "It's a huge leap forward for us. If the trend continues, ship building in Bangladesh will be the second largest exporter after garments in 2015," Presently more than 50,000 skilled workers and 10000 semi-skilled workers are employed in the shipbuilding and dockyard industries. A lot of Diploma Mechanical Engineers are working in this field also.

Around 49 public and 272 private Polytechnic Institutes are producing Diploma Engineers in Bangladesh. Intake capacity of them is 57981seats. Maximum Polytechnic Institutes yield Diploma Mechanical Engineers. Diploma Mechanical Engineering course duration is four years. After completed SSC or equivalent level like Dhakhil, O-level etc. students can admit in the Polytechnic Institute. Mechanical Engineering is the branch of engineering that involves the production and usage of heat and mechanical power for the design, production, and operation of machines and tools. It is one of the oldest and broadest disciplines, the field of mechanical engineering is very broad, most of diploma mechanical engineers work for manufacturing companies that make primary and fabricated materials, machinery, electrical, transportation equipment, and shipbuilding industries. So, many students' first choice is mechanical engineering.

The specific objectives of the study were to identify the occupational tasks of shipbuilding Industries and to recommend the ways and means how diploma in mechanical engineering can be made more relevant to the Shipbuilding Industries in Bangladesh. A lot of Diploma-in Mechanical Engineers are being produced in Polytechnic Institutes every year in Bangladesh. The ship building industry as working fields of Mechanical Engineers is very common. In Bangladesh this fields are increasing rapidly. Bangladesh has huge manpower resources. It was reported in third International Impression-2013 that Ships build in Bangladesh would cost 15\% less compared to competing countries. It can be 3rd Largest export earner within 10 years. Development of maritime manpower is always one of the major concerns of labor management in Bangladesh. It is true that a lot of Diploma mechanical engineers have demanded now in this field.

The study was delimited to manage engineers those who were employing in Shipbuilding Industries. The famous Shipbuilding Industries are established in the bank of river Burtuiganga (Dhaka-Narayangonj), Megnah (Narayangonj), Karnafuli (Chittagong), Rupsha (Khulna), Kirtonkhola (Barisal) and the coastal area of Bay of Bangle in Bangladesh. So, huge time and money needed to collect data from the populations. It was not possible for the researchers to materialize it easily. So the researchers kept the study limited within the selected sample of shipbuilding industries in Bangladesh.

\section{METHODOLOGY}

The researchers have taken 'A' \& 'B' categories Shipbuilding Industries in Bangladesh as population of industries. Only 'A' category shipbuilding industries had sufficient manpower with engineers and all set of works, instruments, workshop and other facilities needed for a standard shipbuilding industry. The 'B' category shipbuilding industries had no sufficient engineers and all set of works, instruments, and other facilities. The researcher found only 5(six) shipbuilding industries as ' $A$ ' category and only 5(six) shipbuilding industries as 'B' category shipbuilding industry in Bangladesh. The population of respondents of the study comprised of Diploma Engineers, B.Sc. Engineers, M.Sc. Engineers, and Doctorate Degree holders who were related to Mechanical / Shipbuilding Engineering or Naval Architect working in those Shipbuilding Industries in Bangladesh. The researcher took purposively five ' $A$ ' category shipbuilding industries and one ' $\mathrm{B}$ ' category shipbuilding industry which had sufficient manpower with engineers and all set of works, instruments, workshop and other facilities total six shipbuilding industries as sample. The respondents sample was selected by using the non-probability convenience sampling technique. Here the sample comprised subjects who were simply available in a convenient way and they were willing to cooperate for providing required information. The total respondents' sample of this study was 60 . The Table 3.1 below shows the selected shipbuilding Industries and number of respondents from each Shipbuilding Industries. 
Table-1 Selected Shipbuilding Industries and category wise number of selected respondents.

\begin{tabular}{l|l|l|l|l|l|l}
\hline \multirow{2}{*}{ No } & Name of the selected Shipbuilding & \multicolumn{2}{l}{ Category Wise Number of Respondents } \\
\cline { 3 - 7 } & Industries & Dip. Engr. & B.Sc. Engr. & M.Sc. Engr. & PhD. & Total \\
\hline 1 & Ananda Shipyard and Shipways, & 6 & 3 & 1 & 0 & 10 \\
\hline 2 & Khulna Shipyard, & 12 & 3 & 0 & 0 & 15 \\
\hline 3 & Khan Brothers Shipbuilding, & 2 & 3 & 0 & 1 & 6 \\
\hline 4 & Highspeed Shipbuilding, & 1 & 6 & 0 & 0 & 7 \\
\hline 5 & Meghna Shipbuilders \& Dockyard Ltd. & 7 & 4 & 0 & 0 & 11 \\
\hline 6 & Western Marine Shipyard, & 7 & 3 & 1 & 0 & 11 \\
\hline & Total & 35 & 22 & 2 & 1 & 60 \\
\hline
\end{tabular}

The researchers used the structured questionnaires to gather information regarding the opinions of engineers who were working in shipbuilding industries about the occupational tasks which were related to the course curricula of 4 year Diploma-in-Mechanical Engineering in Shipbuilding Industries. The questions were designed both structured and unstructured way in the questionnaires. The answers of the questions came out about the relevance of Diploma-in-Mechanical Engineering Course Curriculum of BTEB with the different occupations of ship building industries and also the problems faced by the graduates of Polytechnic Institutes when they work in that field in Shipbuilding Industries. There were five questionnaires designed for gathering data from Engineers who were then working in Shipbuilding Industries. The questionnaires (survey instruments) were developed by the author. These questionnaires were presented to two senior professors and three assistant professor of TVE department of IUT for their comments and for validation purpose. After getting their comments necessary corrections were done and they were finalized for data collection. The research data were collected through extensive review of literature, field visits, survey, BTEB, International Seminar and Exhibition on Prospects of Shipbuilding Industries in the OIC countries, and its related stakeholders. Selected private and public shipyards around the country were visited to collect primary data from professional employees of the Shipbuilding Industries. The developed instruments with structured and open ended questionnaires were administered and collected from the respondents through personal contact. Secondary information about shipbuilding and curriculum of 4-year Diploma-in-Mechanical Engineering was collected from BTEB, Web publications, Prospectus, News Papers, Polytechnic Institutes and other sources.

Copies of questionnaires were administered to the selected respondents and collected immediately after completion by the respondents.

For the analysis of the data, Chi square test, Weighted Average, SPSS (Statistical Package for Social Science) software version 20.0 Evaluation production mode and Microsoft Office Excel 2007 were used. The data from the questionnaires were put in the SPSS software. The weighted average and chi-square test were calculated directly from the raw data in SPSS software. Chi square test was used in finding out whether the opinions of the respondents were statistically significant or not. The significant value was compared with the critical value at 0.05 levels. Some data were analyzed where simple percentages were used. Beyond these the results were also shown in table 2 for more explanations. This helped a clear presentation of the data.

Table 2: Interpretation of the Weighted Average

\begin{tabular}{l|l}
\hline Weighted Average (WA) & Weighted Average Interpretation \\
\hline $4.5 \leq$ WA & Most Relevant (5) \\
\hline $3.5 \leq 4.5 \mathrm{WA}$ & Very Relevant (4) \\
\hline $2.5 \leq 3.5 \mathrm{WA}$ & Relevant (3) \\
\hline $1.5 \leq 2.5 \mathrm{WA}$ & To Some Extent Relevant (2) \\
\hline $1 \leq 1.5 \mathrm{WA}$ & Not Relevant (1) \\
\hline
\end{tabular}

Weighted Average was calculated from the respondents' opinion in each statement using the following formula:

$$
W A=\frac{5 N_{1}+4 N_{2}+3 N_{3}+2 N_{4}+N_{5}}{\mathrm{~N}}
$$

Where;

$\mathrm{N}$ stands for total number of respondents and

$\mathrm{N}_{1}, \mathrm{~N}_{2}, \mathrm{~N}_{3}, \mathrm{~N}_{4}$ and $\mathrm{N}_{5}$ stands for numbers of respondents in different

categories respectively.

Chi-square test was calculated from the respondents' opinion in each statement using the following formula: 


$$
\chi^{2}=\sum\left[\frac{(f o-f e)^{2}}{f e}\right]
$$

Where;

$f_{o}=$ Observe frequency

$f_{e}=$ Expected frequency

III. FINDINGS

Table 3: Opinions of the respondents to extent relevance of 4-year Diploma-in-Engineering Program Mechanical Technology syllabus of the subject of Mechanical Engineering Drawing $-1 \& 2$.

\begin{tabular}{|c|c|c|c|c|c|c|c|c|}
\hline \multirow[b]{2}{*}{$\begin{array}{l}\text { Occupational Tasks } \\
\text { Theory Part }\end{array}$} & \multicolumn{6}{|c|}{ Degree of Relevance } & \multirow[b]{2}{*}{$\chi^{2}$} & \multirow[b]{2}{*}{$\begin{array}{l}\text { Asym } \\
\text { p. } \\
\text { Sig. }\end{array}$} \\
\hline & $\begin{array}{c}\text { Most } \\
\text { Releva } \\
\text { nt } \\
{[5]}\end{array}$ & $\begin{array}{l}\text { Very } \\
\text { Relev } \\
\text { ant } \\
{[4]}\end{array}$ & $\begin{array}{c}\text { Relev } \\
\text { ant } \\
\text { [3] }\end{array}$ & $\begin{array}{c}\text { To } \\
\text { Some } \\
\text { Exten } \\
\text { t } \\
\text { Relev } \\
\text { ant } \\
{[2]}\end{array}$ & $\begin{array}{l}\text { Not } \\
\text { Rele } \\
\text { vant } \\
{[1]}\end{array}$ & $\begin{array}{l}\text { W } \\
\text { A }\end{array}$ & & \\
\hline $\begin{array}{l}\text { 1. The concept of "Free hand sketching, } \\
\text { deferent type of drawing, projection } \\
\text { drawing. }\end{array}$ & 25 & 20 & 12 & 3 & 0 & 4.1 & 37.83 & 0.00 \\
\hline $\begin{array}{l}\text { 2. The Oblique drawing, Isometric } \\
\text { drawing. }\end{array}$ & 24 & 24 & 12 & 0 & 0 & 4.2 & 44.50 & 0.00 \\
\hline $\begin{array}{l}\text { 3. The concept of section drawing, } \\
\text { Screw Threads, Fastener. }\end{array}$ & 27 & 24 & 8 & 0 & 0 & 4.3 & 56.00 & 0.00 \\
\hline $\begin{array}{l}\text { 4. Auxiliary views planes, Electrical } \\
\text { Circuit Drawing. }\end{array}$ & 30 & 20 & 9 & 1 & 0 & 4.3 & 56.00 & 0.00 \\
\hline $\begin{array}{l}\text { 5. Drawings, related to different } \\
\text { Industrial Pipes, Gears. }\end{array}$ & 32 & 20 & 8 & 0 & 0 & 4.4 & 61.83 & 0.00 \\
\hline $\begin{array}{l}\text { Practical Part: } \\
\text { 1.Prepare freehand sketches of } \\
\text { Mechanical components, Prepare } \\
\text { /drawing, Isometric drawing. }\end{array}$ & 23 & 27 & 9 & 2 & 0 & 4.2 & 47.33 & 0.00 \\
\hline $\begin{array}{l}\text { 2. Construct first and third angle } \\
\text { orthographic views, ISO sectioning } \\
\text { conventions. }\end{array}$ & 22 & 25 & 12 & 2 & 0 & 4.1 & 42.66 & 0.00 \\
\hline $\begin{array}{l}\text { 3. Prepare the industrial pipe work } \\
\text { drawing. }\end{array}$ & 27 & 25 & 8 & 0 & 0 & 4.3 & 56.00 & 0.00 \\
\hline $\begin{array}{l}\text { 4. Construct the sectional views of } \\
\text { simple engineering parts, Prepare the } \\
\text { drawing conventions of thread } \\
\text { fastening devices, The working } \\
\text { drawing of gears. }\end{array}$ & 15 & 27 & 15 & 3 & 0 & 3.9 & 38.66 & 0.00 \\
\hline $\begin{array}{l}\text { 5. Construct the auxiliary views of } \\
\text { engineering parts. , the schematic } \\
\text { drawing of an electric circuit. }\end{array}$ & 16 & 25 & 17 & 2 & 0 & 3.9 & 37.66 & 0.00 \\
\hline $\begin{array}{l}\text { 6. Prepare the drawings of riveted and } \\
\text { welded components. }\end{array}$ & 20 & 15 & 15 & 8 & 2 & 3.7 & 16.5 & 0.00 \\
\hline
\end{tabular}

[N.B The value of Chi Square ( $\chi 2)$ was used for testing its significance at 0.05 level of confidence.]

The data presented in table 4-2 reveals that all respondents agreed that

- All the occupational tasks of Mechanical Engineering Drawing - $1 \& 2$ are always required in Shipbuilding Industries. The overall Weight averages of all occupational tasks are very important.

- Chi-Square Test results also showed that all occupational tasks theory and practical are accepted in Shipbuilding Industries.

Opinions of the engineers in open ended questionnaires were: 
"Are the lists of the contents of this subject adequate for the Program of the Diploma-in- Mechanical Engineering Course Curricula which is related to Mechanical Works of Shipbuilding Industries?”

$65 \%$ Respondents answered 'yes' while other 35\% respondent's answers were:

- AutoCAD Drawing is very important in Shipbuilding Industries.(21\% opinions).

- $\quad$ Piping Drawing Software practice is very important in Shipbuilding Industries.(4\% opinions).

- Some marine engineering drawing should be added in the drawing.

Table 4: Opinion of the respondents to extent of degree of relevance of 4-year Diploma-in-Engineering Program Mechanical Technology syllabus of the subject of Basic Workshop Practice.

\begin{tabular}{|c|c|c|c|c|c|c|c|c|}
\hline \multirow[b]{2}{*}{$\begin{array}{l}\text { Occupational Tasks } \\
\text { Practical: }\end{array}$} & \multicolumn{5}{|c|}{ Degree of Relevance } & \multirow[b]{2}{*}{ WA } & \multirow[b]{2}{*}{$\chi^{2}$} & \multirow[b]{2}{*}{$\begin{array}{l}\text { Asym } \\
\text { p. } \\
\text { Sig. }\end{array}$} \\
\hline & $\begin{array}{l}\text { Most } \\
\text { Rele } \\
\text { vant } \\
{[5]}\end{array}$ & $\begin{array}{l}\text { Very } \\
\text { Relev } \\
\text { ant } \\
{[4]}\end{array}$ & $\begin{array}{c}\text { Rele } \\
\text { vant } \\
{[3]}\end{array}$ & $\begin{array}{c}\text { To } \\
\text { Some } \\
\text { Exten } \\
\mathrm{t} \\
\text { Relev } \\
\text { ant } \\
{[2]}\end{array}$ & $\begin{array}{c}\text { Not } \\
\text { Rel } \\
\text { eva } \\
\text { nt } \\
{[1]}\end{array}$ & & & \\
\hline $\begin{array}{l}\text { 1.Understand the safely productions in } \\
\text { Fitting \& welding shop: }\end{array}$ & 27 & 15 & 15 & 3 & 0 & 4.1 & 38.67 & 0.000 \\
\hline $\begin{array}{l}\text { 2. Demonstrate the application of basic } \\
\text { metal working hand tools. }\end{array}$ & 22 & 27 & 10 & 1 & 0 & 4.2 & 38.67 & 0.000 \\
\hline $\begin{array}{l}\text { 3. Demonstrate the application of } \\
\text { measuring instruments and gages for } \\
\text { bench work. }\end{array}$ & 33 & 22 & 5 & 0 & 0 & 4.5 & 48.00 & 0.000 \\
\hline $\begin{array}{l}\text { 4. Demonstrate the application of } \\
\text { machines and equipment for fitting } \\
\text { works. }\end{array}$ & 30 & 25 & 5 & 0 & 0 & 4.4 & 68.00 & 0.000 \\
\hline $\begin{array}{l}\text { 5. Show skill in sawing, chipping, filing, } \\
\text { drilling and reaming. }\end{array}$ & 25 & 25 & 8 & 2 & 0 & 4.2 & 49.67 & 0.000 \\
\hline $\begin{array}{l}\text { 6. Show skill in cutting threads, making } \\
\text { sheet metal jobs. }\end{array}$ & 25 & 17 & 13 & 5 & 0 & 4.0 & 30.33 & 0.000 \\
\hline 7. Show skill in making pipe and duct. & 25 & 20 & 15 & 0 & 0 & 4.2 & 39.67 & 0.000 \\
\hline $\begin{array}{l}\text { 8. Show skill in soldering and brazing, arc } \\
\text { welding. }\end{array}$ & 23 & 22 & 11 & 4 & 0 & 4.1 & 35.33 & 0.000 \\
\hline 9. Show skill in welding by gas. & 20 & 25 & 15 & 0 & 0 & 4.1 & 36.33 & 0.000 \\
\hline 10. Show skill in resistance welding. & 10 & 21 & 13 & 10 & 6 & 3.3 & 12.50 & 0.014 \\
\hline
\end{tabular}

The data presented in Table 4-3 reveals that all respondents agreed that

- The topics of the subject of Basic Workshop Practice 1 to 9 are very relevant and statement 10 is relevant in Shipbuilding Industries.

- Chi-Square Test results are also approved that all practical occupational tasks are accepted in Shipbuilding Industries.

Opinions of the engineers in open ended questionnaires were: "Are the lists of the contents of this subject adequate for the Program of the Diploma-in-Mechanical Engineering Course Curricula which is related to Mechanical Works of Shipbuilding Industries?

$85 \%$ Respondents answered 'yes' on the other hand 15\% respondent's answers were:

- The occupational tasks 8,9,10 were not available in Shipbuilding Industries in Bangladesh (6\% opinions)

- C.N.C cutting machine operating should be added in this subject. (15\% opinions) 
Table 5: Opinion of the respondents to extent of degree of relevance of 4-year Diploma-in-Engineering Program Mechanical Technology syllabus of the subject of Advanced Welding.

\begin{tabular}{|c|c|c|c|c|c|c|c|c|}
\hline \multirow[b]{2}{*}{$\begin{array}{l}\text { Occupational Tasks } \\
\text { Theory Part: }\end{array}$} & \multicolumn{5}{|c|}{ Degree of Relevance } & \multirow[b]{2}{*}{$\begin{array}{l}\text { W } \\
\text { A }\end{array}$} & \multirow[b]{2}{*}{$\chi^{2}$} & \multirow[b]{2}{*}{$\begin{array}{l}\text { Asy } \\
\text { mp. } \\
\text { Sig. }\end{array}$} \\
\hline & $\begin{array}{c}\text { Most } \\
\text { Rele } \\
\text { vant } \\
{[5]}\end{array}$ & $\begin{array}{c}\text { Very } \\
\text { Rele } \\
\text { vant } \\
{[4]}\end{array}$ & $\begin{array}{c}\text { Rel } \\
\text { eva } \\
\text { nt } \\
\\
{[3]}\end{array}$ & $\begin{array}{c}\text { To } \\
\text { Som } \\
\text { e } \\
\text { Exte } \\
\text { nt } \\
\text { Rele } \\
\text { vant } \\
{[2]}\end{array}$ & $\begin{array}{c}\mathrm{N} \\
\text { ot } \\
\mathrm{Re} \\
\mathrm{le} \\
\mathrm{va} \\
\mathrm{nt} \\
{[1]}\end{array}$ & & & \\
\hline $\begin{array}{l}\text { 1.The scope and importance of welding, } \\
\text { the current and voltage of arc welding sets. }\end{array}$ & 38 & 13 & 9 & 0 & 0 & 4.5 & 79.83 & .000 \\
\hline $\begin{array}{l}\text { 2. The electrodes and function of coating } \\
\text { on electrode, the uses of flux and filler } \\
\text { rods. }\end{array}$ & 37 & 22 & 2 & 0 & 0 & 4.6 & 87.66 & .000 \\
\hline 3. The principles of arc welding processes. & 43 & 16 & 1 & 0 & 0 & 4.7 & 110.67 & .000 \\
\hline $\begin{array}{l}\text { 4. The gas welding equipment. Understand } \\
\text { the principles of gas welding. The } \\
\text { principles of gas cutting. }\end{array}$ & 30 & 27 & 3 & 0 & 0 & 4.5 & 79.83 & .000 \\
\hline $\begin{array}{l}\text { 5. The resistance welding processes. The } \\
\text { uses of special welding processes. }\end{array}$ & 25 & 22 & 12 & 6 & 5 & 3.8 & 21.17 & .000 \\
\hline $\begin{array}{l}\text { 6.The techniques of welding of different } \\
\text { metals. The defects of welding and their } \\
\text { causes. }\end{array}$ & 30 & 23 & 7 & 0 & 0 & 4.4 & 63.17 & .000 \\
\hline $\begin{array}{l}\text { 7. The codes and standard used in high } \\
\text { pressure welding. The principles of testing } \\
\text { of welding joints. }\end{array}$ & 28 & 26 & 7 & 0 & 0 & 4.3 & 61.33 & .000 \\
\hline
\end{tabular}

\section{Practical Part:}

\begin{tabular}{l|l|l|l|l|l|l|l|l}
\hline $\begin{array}{l}\text { 1. Perform lap joint and double Vee butt } \\
\text { joint by arc welding process. }\end{array}$ & 40 & 16 & 4 & 0 & 0 & 4.6 & 95.17 & .000 \\
\hline $\begin{array}{l}\text { 2. Perform the butt joint of aluminum } \\
\text { plates, butt joint of cast iron plates, butt } \\
\text { joint of GI pipes, butt joints by oxy- } \\
\text { acetylene gas welding of mild steel plates. }\end{array}$ & 35 & 18 & 7 & 0 & 0 & 4.5 & 71.33 & .000 \\
\hline $\begin{array}{l}\text { 3. Perform lap joint of stainless steel } \\
\text { plates. Lap/butt joint with aluminum } \\
\text { bars/plates, copper bars/plates and stainless } \\
\text { steel bars with plates. }\end{array}$ & 28 & 27 & 3 & 0 & 0 & 4.4 & 41.83 & .000 \\
\hline $\begin{array}{l}\text { 4. Perform Brazing of steel pipes, Perform } \\
\text { joints of GI and stainless sheet with } \\
\text { resistance welding set. }\end{array}$ & 6 & 22 & 21 & 6 & 0 & 3.5 & 75.67 & .000 \\
\hline $\begin{array}{l}\text { 5. Perform the joint of stainless steel plate } \\
\text { by TIG, the joints of stainless steel plate by } \\
\text { MIG. }\end{array}$ & 32 & 17 & 11 & 0 & 0 & 4.4 & 56.33 & .000 \\
\hline $\begin{array}{l}\text { 6. Perform the work of joining of broken } \\
\text { shaft tube well pipe by thermit welding. }\end{array}$ & 12 & 17 & 26 & 5 & 0 & 3.6 & 46.33 & .000 \\
\hline $\begin{array}{l}\text { 7. Perform the Dye penetration test at the } \\
\text { welding joints for finding defect. }\end{array}$ & 15 & 40 & 2 & 3 & 3 & 4.0 & 93.00 & .000 \\
\hline $\begin{array}{l}\text { 8. Perform microscopic examination at the } \\
\text { welding joint, the radiographic test at the } \\
\text { welding joint, the tension test at the } \\
\text { welding joint. }\end{array}$ & 22 & 25 & 12 & 1 & 0 & 4.1 & 42.67 & .000 \\
\hline
\end{tabular}


The data presented in table 4-4 indicates that all respondents agreed that:

- The occupational tasks of 1, 2, 3 and 4 in theory part and the occupational tasks of 1 and 2 in practical part are the most relevant.

- The occupational tasks of 5,6 and 7 in theory part and the occupational tasks of 3, 4, 5, 6 and 7 in practical part are very relevant of the subject of Advanced Welding which is always required in Shipbuilding Industries.

- Chi-Square Test results are also approved that all theoretical and practical occupational tasks are accepted in Shipbuilding Industries.

Opinions of the engineers in open ended questionnaires were:

"Are the lists of the contents of this subject adequate for the Program of the Diploma-in- Mechanical Engineering Course Curricula which is related to Mechanical Works of Shipbuilding Industries?

In respond to the above question 92\% respondents answered 'yes' and rest other 08\% respondent's answers were:

- The occupational tasks of 5, 6, and 7 in theory part are not available in Shipbuilding Industries in Bangladesh.(8\% opinions)

- $\quad$ Robotic Welding should be added in this subject.(4\% opinions)

Table 6: Opinion of the respondents to extent of degree of relevance of 4-year Diploma-in-Engineering Program Mechanical Technology syllabus of the subject of Special Welding.

tional Tasks

Theory Part: machines and equipment. The techniques of TIG welding.

2. The MIG techniques of welding process. State the principles of MIG welding.

3. The techniques of Various G- position welding.

4. The concept of plasma arc cutting, The techniques of plasma welding.

5 . The basic concepts of electron beam welding, the techniques of ultrasonic welding.

6. The basic concept of laser welding.

7. The techniques of underwater cutting.

\begin{tabular}{|c|c|c|c|c|c|c|c}
\multicolumn{6}{c|}{ Degree of Relevance } & \multicolumn{2}{l}{} \\
\hline $\begin{array}{c}\text { Most } \\
\text { Rele } \\
\text { vant } \\
{[5]}\end{array}$ & $\begin{array}{c}\text { Very } \\
\text { Rele } \\
\text { vant } \\
{[4]}\end{array}$ & $\begin{array}{c}\text { Rel } \\
\text { eva } \\
\text { nt } \\
{[3]}\end{array}$ & $\begin{array}{c}\text { To } \\
\text { Some } \\
\text { Exte } \\
\text { nele } \\
\text { vant } \\
{[2]}\end{array}$ & $\begin{array}{c}\text { Not } \\
\text { Rel } \\
\text { eva } \\
\text { nt } \\
{[1]}\end{array}$ & WA & $\chi^{2}$ & $\begin{array}{c}\text { Asy } \\
\text { mp } \\
\text { Sig. }\end{array}$ \\
\hline 37 & 13 & 10 & 0 & 0 & 4.5 & 87.67 & .000 \\
\hline 36 & 19 & 11 & 0 & 0 & 4.3 & 79.83 & .000 \\
\hline 31 & 17 & 8 & 4 & 0 & 4.3 & 21.17 & .000 \\
\hline 10 & 15 & 15 & 8 & 12 & 3.1 & 76.00 & .049 \\
\hline 0 & 5 & 12 & 18 & 25 & 2.0 & 61.33 & .054 \\
\hline 36 & 4 & 14 & 13 & 27 & 2.0 & 71.33 & .265 \\
\hline
\end{tabular}

\section{Practical Part:}

1. Set up the TIG welding equipment. Perform the welding (TIG) of Stainless steel butt joint in flat position, the welding (TIG) of aluminum fillet joint in flat position.

2. Perform the welding (MIG) of mild steel butt joint in flat position. the welding (MIG) of mild steel fillet joint in flat position.

3.Set up MIG (Metal Inert Gas) welding equipment. Perform the MIG butt weld in flat position, fillet weld in flat position.

4. Perform the welding (arc) of thin wall pipe by downhill process, the welding (arc) of thick wall pipe by uphill process.

5. Perform the welding (arc) of plate and pipe in various G-position.

\begin{tabular}{|c|c|c|c|c|c|c|c}
17 & 23 & 20 & 0 & 0 & 4.0 & 61.33 & .000 \\
\hline 12 & 27 & 21 & 0 & 0 & 3.9 & 75.67 & .000 \\
\hline 28 & 27 & 1 & 2 & 2 & 4.3 & 41.83 & .000 \\
\hline
\end{tabular}


The data presented in table 4-5 shows that all respondents agreed that:

- The occupational tasks of 1 and 3 in theory part are the most relevant.

- The occupational tasks of 2 and 4 in theory part and the occupational tasks 1, 2, 3, 4 and 5 in practical part are very relevant.

- The occupational task of 5 is important and the occupational tasks of 6 and 7 are somewhat relevant in the theory part of the subject of Special Welding in Shipbuilding Industries.

- Chi-Square Test results are also approved that all theoretical and practical occupational tasks are accepted in Shipbuilding Industries without the occupational tasks of 5, 6 and 7 in the theory part.

Opinions of the engineers in open ended questionnaires were:

"Are the lists of the contents of this subject adequate for the Program of the Diploma-in-Mechanical Engineering Course Curricula which is related to Mechanical Works of Shipbuilding Industries?

In respond to the above question $90 \%$ Respondents answered 'yes' while $10 \%$ respondent's answers were:

- Welding course is very essential in shipbuilding industries.(2\%opinions)

- Give more emphasis on the welding of practical subject. (10\% opinions)

\section{CONCLUSION AND RECOMMENDATION}

The research revealed that all occupational tasks of the subject of Mechanical Engineering Drawing - 1 \& 2 are always required in Shipbuilding Industries. The overall WA of all occupational tasks are very important. All occupational tasks of the subject of Basic Workshop Practice are very relevant in Shipbuilding Industries. The analysis of the open ended questions for the engineers and managers of Shipbuilding Industries revealed that: (i) AutoCAD is very important; (ii) Piping Drawing Software practice is important; (iii) Some marine engineering drawing should be added in the drawing subjects; (iv) C.N.C cutting should be added; (v) The works of the techniques of underwater cutting, laser welding, electron beam welding and ultrasonic welding are not available in Shipbuilding Industries in Bangladesh; (vi) Robotic Welding should be added in the subject of special welding; (vii) Welding course is needed in shipbuilding industries; (viii) Give more emphasis in practical on welding; (ix) One subject related with shipbuilding should be included in the course of Diploma-in Mechanical Engineering Bangladesh Shipbuilding Industry is a promising sector. Bangladesh has huge manpower resources. Development of maritime manpower is always one of the major concerns of labor management in Bangladesh. A lot of diploma mechanical engineers have demand now in this field and it will increase in near future. The findings of analyzed results according to opinion of the respondents revealed that some new subjects can be added with 4-Year Diploma-in-Mechanical Engineering Course Curriculum. Name of the subjects already recommended in this study. In some subjects some new contents would be added for further development of the present curricula. Those are some subjects like Robotic Welding, Piping Drawing Software, Some marine engineering drawing, C.N.C cutting machine and AutoCAD Drawing. The results revealed that the occupational tasks of shipbuilding industries have strong relationship and similarity with the course curricula of 4-Year Diploma-in- Mechanical Engineering. In the light of the findings following recommendations were made for taking actions by the BTEB authority for development quality in future of 4-Year Diploma-in- Mechanical Engineering. (i) In practical part of the subject "Advanced Welding" should be reorganized on the basis of different level of sub-domain of psychomotor domain; (ii) The curriculum developers should emphasis on more 'Articulation' and 'Naturalization' of psychomotor domain in the subject of 'Basic Workshop Practice' in the syllabus; (iii)The curriculum developers should add more 'Precision' and 'Naturalization' of Psychomotor action verbs in the subject of Computer Application-II in syllabus; (iv) AutoCAD should practice in the drawing subject; (v) Piping Drawing Software should practice in the drawing subject; (vi) Some marine engineering drawing should be added in the drawing subjects; (vii) C.N.C cutting machine operating should be added in a relevant subject; (viii) Robotic Welding should be added in special welding subject; (ix) It should be given more emphasis on the welding of practical subject; (x) One subject related with shipbuilding technology should be included in the course of Diploma-in Mechanical Engineering for example 'Basic Shipbuilding' or 'Ship Yard Practice' or 'Shipbuilding materials'.

\section{REFERENCES}

[1] Hossin, A. (2010). "A study of the relationship between occupational skills provided to polytechnic diploma engineers by BTEB and requirement of industry of Bangladesh".

[2] Iqbal (2010) Performance evaluation of the contemporary shipbuilding industries in Bangladesh, Retrieved on October, 23, 2023 from the Web http://www.banglajol.info

[3] Marine TECH Bangladesh (2013). Report on Third International Impression, 2013.

[4] Third International Impression, Dhaka (2013), Marine Industrial Equipment, Shipbuilding and Navel Architectural Design, Training \& Education Expo.

[5] Zakaria (2010). Performance evaluation of the contemporary shipbuilding industries in Bangladesh, Journal of Naval Architecture and Marine Engineering. 